\title{
A METHOD FOR PREDICTING RATCHETING AND WEAR IN ROLLING CONTACT FATIGUE, TAKING TECHNOLOGICAL RESIDUAL STRESSES INTO CONSIDERATION
}

\author{
Radim Halama, Michal Šofer, Jaroslav Rojíček, František Fojtík, Kamil Kolařík
}

Original scientific paper

The main aim of our study is to show the influence of residual stresses on wear and surface ratcheting in the case of line rolling contact. Experiments were carried out on the innovated TUORS (Technical University of Ostrava Rolling Sliding testing machine) testing rig under free rolling and also under a slip ratio of $0,75 \%$. All specimens used for the experiments were made from R7T steel. A hole-drilling method and an X-ray diffraction method were applied to determine the residual stresses induced by repeated contact loading and technological residual stresses. Mazzu's semi-analytical approach, which makes use of full integration of the Armstrong-Frederick model, was used to simulate ratcheting and wear. The proposed model calibration methodology, based on an inverse approach, allows the model parameters to be determined directly from the measured wear. The results of this study confirm that the observed technological compressive residual stresses lead to lower ratcheting and subsequently also to lower wear rates.

Keywords: ratcheting; residual stress; rolling contact fatigue; wear

\section{Metoda za predviđanje plastične deformacije i trošenja kod zamora materijala zbog dodira valjanjem uzimajući u obzir tehnološka zaostala naprezanja}

Izvorni znanstveni rad

Glavni cilj našega rada je pokazati utjecaj zaostalih naprezanja na trošenje i plastičnu deformaciju (ratcheting) površine u slučaju linijskog dodira valjanjem. Pokusi su provedeni na obnovljenoj TUORS (Technical University of Ostrava Rolling Sliding testing machine) opremi za ispitivanje kod slobodnog valjanja i također kod omjera klizanja od $0,75 \%$. Svi uzorci korišteni za pokuse izrađene su od čelika R7T. Metoda bušenja rupe i metoda rendgenske difrakcije primijenjene su kako bi se odredila zaostala naprezanja uzrokovana ponavljajućim dodirnim opterećenjem i tehnološki zaostalim naprezanjima. Za simulaciju plastične deformacije i trošenja primijenjen je Mazzuov polu-analitički pristup, koji koristi punu integraciju Armstrong Frederick modela. Predložena metodologija kalibriranja modela na temelju inverznog pristupa, omogućuje određivanje parametara modela izravno iz izmjerenog trošenja. Rezultati ovog istraživanja potvrđuju da promatrana tehnološka tlačna zaostala naprezanja dovode do smanjenja plastične deformacije, stoga i do nižeg stupnja trošenja.

Ključne riječi: plastična deformacija; trošenje; zamor zbog dodira valjanjem; zaostalo naprezanje

\section{Introduction}

The interaction between rail and wheel involves a very complex set of problems [1, 2], including phenomena such as material hardening of the surface and subsurface layers, the distribution of residual stresses, and the fatigue crack propagation mechanism [3, 1]. The phenomenon of plastic deformation accumulation, also called ratcheting, has been recognized as the dominant wear mechanism in dry rolling/sliding contact, rather than low-cycle fatigue [3]. As shown by Tyfour et al. [4], there is a critical shear strain value at which the material shows steady wear behavior. Stabilized growth of short surface cracks corresponds to reaching the critical strain in deeper material layers. Tyfour et al. also point out a relationship between wear and ratcheting that can reach steady state under certain conditions [4].

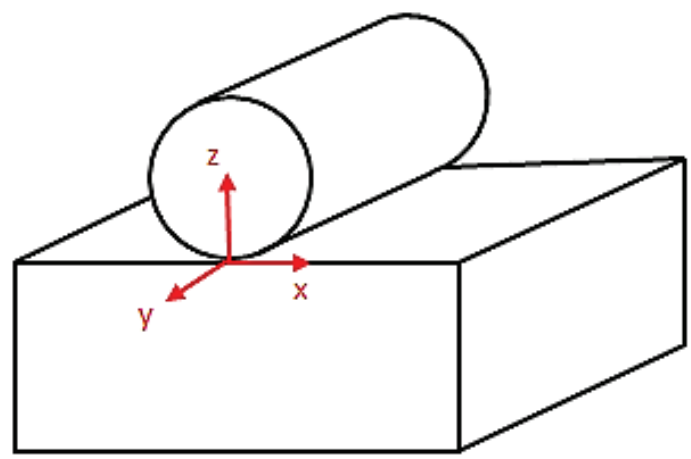

Figure 1 Considered coordinate system
However, Fletcher and Beynon [5] have observed equilibrium between crack growth and wear. They describe crack growth itself in two steps: crack initiation due to ratcheting and crack propagation due to shear stress. The crack initiation phase is also caused by reaching accumulated critical plastic deformation at a particular depth [6]. In most cases, nucleated cracks grow parallel to the contact surface and cause material delamination (flanking phenomena) [7]. Merwin and Johnson [8] point to orthogonal shear strain deformation $\gamma_{x z}$ (see Fig. 1) as the only component that can be accumulated in the process of repeated contact between two bodies.

In 1989, Bower and Johnson [9] presented a nonlinear model with kinematic hardening, considering $\tau_{x z}$ as the only component responsible for material flow in the contact. The model showed relatively satisfactory results only in the case of subsurface flow, which is significantly influenced by the $\tau_{x z}$ stress component (see Fig. 1). The model was therefore not suitable for predicting the surface flow, where the accumulation process of plastic shear deformation is significantly affected by $\sigma_{x}$.

Due to the possibility of a large number of calculation cycles, semi-analytical methods are very popular. In 1993, Dang Van and Maitournam presented an approach for calculating the residual stress and deformation during rolling contact [10]. The basic idea is the assumption of a steady state in the reference coordinate system that shifts with the load. The authors divided this method into two computational methods, which are then applied in 2D analyses $[10,11]$. Their ability to use the $3 \mathrm{D}$ Fourier 
transform was then mentioned in [10]. A later approach, published by Jiang and Sehitoglu [13], is based on the assumption of an elastic stress field in the material and the application of procedures for the subsequent relaxation of stresses and strains [13]. A different approach was proposed by Mazzu [14], who presented a simplified nonlinear kinematic hardening model based on the ChabocheLemaitre plasticity model. According to Mazzu, the only component responsible for plastic flow is $\tau_{x z}$. One year later, Mazzu published a correction of his algorithm, in which he also considered the influence of component $\sigma_{x}$, which significantly influences the plastic flow in the surface layers without making increased demands on computing time. The results published in [1] and [15] show good conformity with the experimental data.

Fatigue life under rolling contact is also significantly influenced by the residual stress depth distribution, as demonstrated in, for example, [16] and [17] on the basis of results conducted by Finite Element Method (FEM). Direct introduction of technological residual stresses into semi-analytical models is problematic.

This paper focuses on ratcheting and wear prediction with the inclusion of these residual stresses in the numerical simulations. The elastic stress field needed for subsequent computations with the Mazzu algorithm is originally obtained using the Boussinesq approximation. However, the main goal was to observe the influence of the residual stresses that govern the elasto-plastic stress distribution. For these purposes, we have used the FEM model, including experimentally measured technological residual stresses as the initial stresses. In addition to a newly applied methodology for including residual stresses in the elasto-plastic stress field, we have also applied a new procedure for identifying the Chaboche plasticity model material parameters. The procedure is based on an algorithm with a random number generator.

\section{Experiments}

Altogether, three different types of experimental tests were performed. In the first step, a rolling contact fatigue test was performed for R7T wheel steel under particular loading conditions. In the next step, it was necessary to inspect the change of the residual stresses with depth. For this purpose, a hole-drilling method and an X-ray method were used. The following chapter contains a description of the methods used for acquiring the final experimental data.

\subsection{Rolling contact fatigue tests}

All rolling contact wear tests were performed in the Rolling Contact Fatigue Laboratory at the Department of Mechanics of Materials of VŠB-Technical University of Ostrava, using the TUORS testing machine, which was described in [18] and can be seen in the photograph in Fig. 2. The diameter of the wheel disc (made of R7T steel) was $82,45 \mathrm{~mm}$, while the diameter of the rail disc (made of class C steel) was $215,55 \mathrm{~mm}$.

The difference between the diameters of the gears and the diameters of the specimens led to creepage of $0,75 \%$. The Hertzian contact pressure was $1200 \mathrm{MPa}$ for all tests considered in this paper. The wheel discs were the object of interest, so the test results are presented for R7T steel only. During the entire test, we also recorded the torque on the shaft carrying the wheel disc. The record was then used for obtaining the dependence of the traction coefficient on the number of cycles [18]. Disc weight loss, disc diameter loss, hardness, and surface roughness were investigated at the end of the tests. After sectioning of the specimen, a metallographic inspection of the surface layer was carried out in order to evaluate the maximum defects and the shear strain accumulation [18].

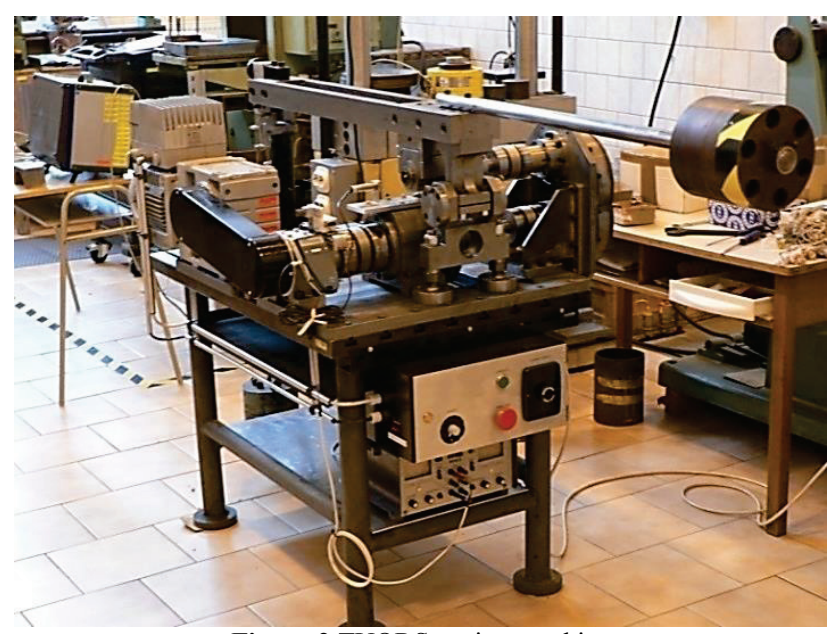

Figure 2 TUORS testing machine

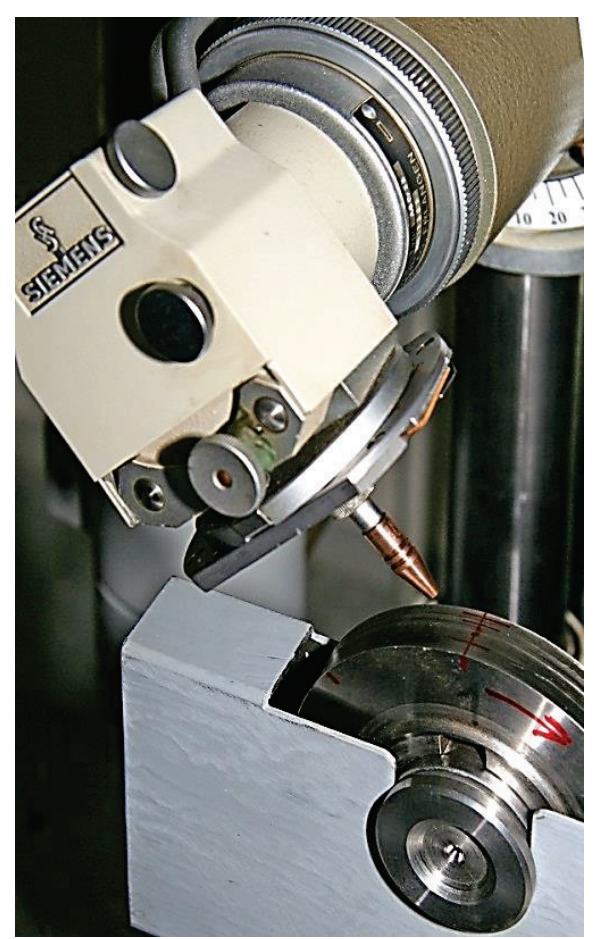

Figure 3 XRD "one-tilt" method experimental set-up

\subsection{X-ray measurements}

The X-ray measurements were made in the X-ray diffraction (XRD) laboratory of the Czech Technical University in Prague. The XRD "one-tilt" method (see Fig. 3) was applied in a study of the biaxial state of residual stresses (RS) [22]. This method is based on conducting an evaluation of the changes in the crystal lattice parameter, which are interpreted as macroscopic residual stresses. An X-ray diffraction experiment was 
carried out on the IsoDebyeflex3003 device. The incident $\mathrm{X}$-ray $\mathrm{CrK} \alpha$ beam directed by a cylindrical collimator 1,7 $\mathrm{mm}$ in diameter reached the sample surface at an angle $\psi_{0}$ $=45^{\circ}$ in the axial and transversal directions, in which the surface components of the stress, $\sigma_{\mathrm{A}}$ and $\sigma_{\mathrm{T}}$ respectively, were analysed. A record of the $\{211\} \alpha-F e$ diffraction line intensity profile was obtained using an image plate position sensitive detector. The effective penetration depth of the X-ray beam was approximately $5 \mu \mathrm{m}$. The cross-correlation method was utilized to evaluate the diffraction data, and the X-ray elastic constant $1 / 2 s_{2}=$ $5,76 \times 10^{-6} \mathrm{MPa}^{-1}$ was used for the stress calculations. The experimental inaccuracy did not exceed $40 \mathrm{MPa}$ (see $[19 \div 21])$

\subsection{Hole-drilling method measurements}

The principle of the semi-destructive hole-drilling method is based on measuring the strains released in the neighborhood of cylindrical holes drilled at selected points in the investigated component. The released strains were measured by strain gauge methods with the use of special rectangular strain gauges in the form of RY 61$120 / \mathrm{S}$ rosettes, made by Hottinger, with strain gauge grids $1,6 \mathrm{~mm}$ in length. Cylindrical holes were drilled successively in the centres of these rosettes, in six depth steps. The drilled holes were 1,6 $\mathrm{mm}$ in diameter and 1,6 $\mathrm{mm}$ in depth. A Vishay P-3500 static strain gauge apparatus was used for measuring the released relative strains.

The distribution of the residual stresses along the depth of the drilled hole was evaluated from the measured released relative strains at individual steps while the circular hole was being drilled. An evaluation of the mean value of the residual stresses can be made in accordance with US standard ASTM 837 [23] using the methodology of the Hottinger company [25] or the method published and recommended by Vishay [26]. The changes of the residual stresses along the depth of the drilled hole were evaluated by the integral method described in [24].

\subsection{Experimental results}

A comparison of the principal residual stresses induced by a certain number of rolling contact cycles measured at a selected location is shown in Fig. 4. With increasing number of cycles, the residual stresses clearly increase mainly for the minimum principal stress, which acts in the circumferential direction. Technological residual stresses in a blank cylindrical specimen, measured by the hole-drilling method, are also shown in Fig. 4. It should be noted that the residual stresses originate from heat treatment and surface machining of the wheel disc specimen.

\section{Computational study}

A previous paper by our team [18] shows that FE simulation of the rolling contact gives a ratcheting prediction comparable to the experimental results, and the cyclic plasticity model used in the computation correctly describes a multiaxial ratcheting test realized under reverse tension and repeated torsion non-proportional loading. The same FE model with the AbdelKarim-Ohno material option [18] was used for the elastoplastic simulations in this study. The FE results are applied as input for subsequent semi-analytical predictions of ratcheting and wear for the rolling contact case with creepage of $0,75 \%$ in order to study the influence of technological residual stresses on ratcheting and wear.
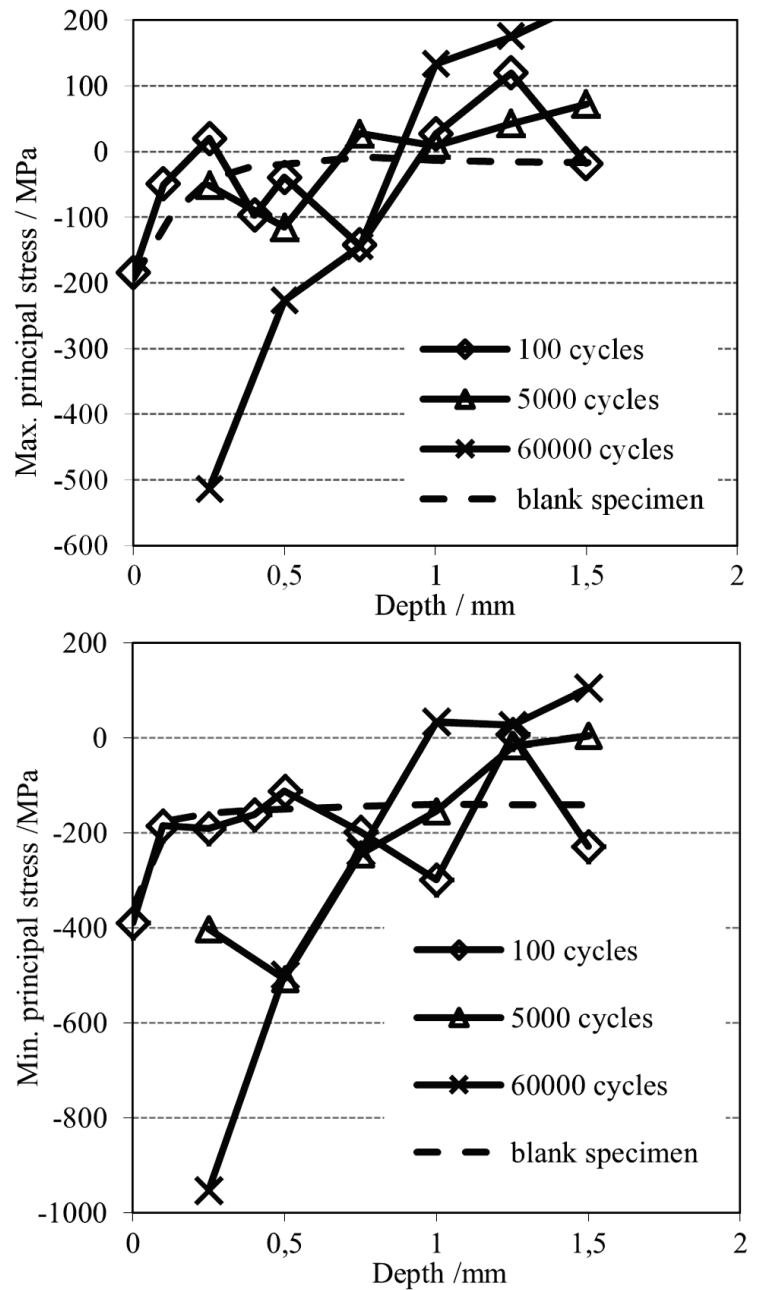

Figure 4 The distribution of maximum and minimum residual stresses (surface: the X-ray method; subsurface: the hole-drilling method)

\subsection{FEM}

The two-dimensional elastoplastic FE analysis was carried out under the assumption of the plane strain condition: that the width of the specimen is much greater than the width of the contact area. Eight hundred rolling cycles were simulated by shifting the normal and shear stress distributions on the surface, using a strategy described in [18]. The AbdelKarim-Ohno model was implemented in the ANSYS program to obtain an accurate prediction of uniaxial and multiaxial ratcheting for the investigated R7T wheel steel. All material parameters and other parameters of the FE computations have been reported elsewhere [18]. The only difference from the previous FE analysis is that the technological residual stresses are considered as initial stresses.

Fig. 5, which compares the results from the two FE computations, shows that there is a significant influence on ratcheting prediction. 


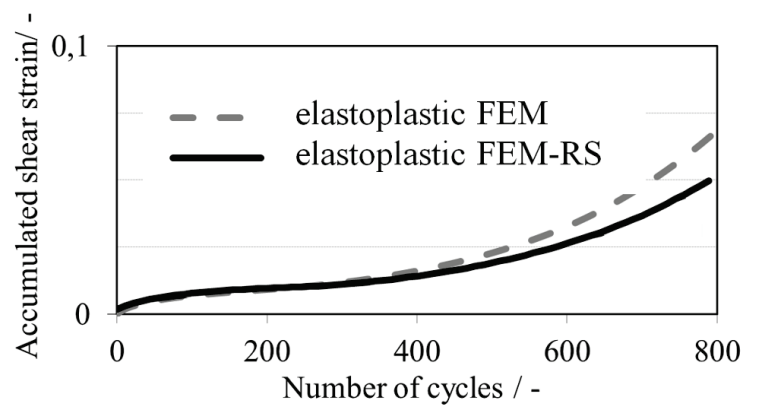

Figure 5 Predicted accumulation of shear strain (FEM results were published in [18])

Figs. 6 and 7 display the trend of shear stress $\tau_{\mathrm{xz}}$ and normal stress $\sigma_{x}$ as a function of depth. As can be seen, the applied initial compressive residual stresses have a positive influence on the minimum, maximum, and mean values of the distribution of the components of the stress tensor.

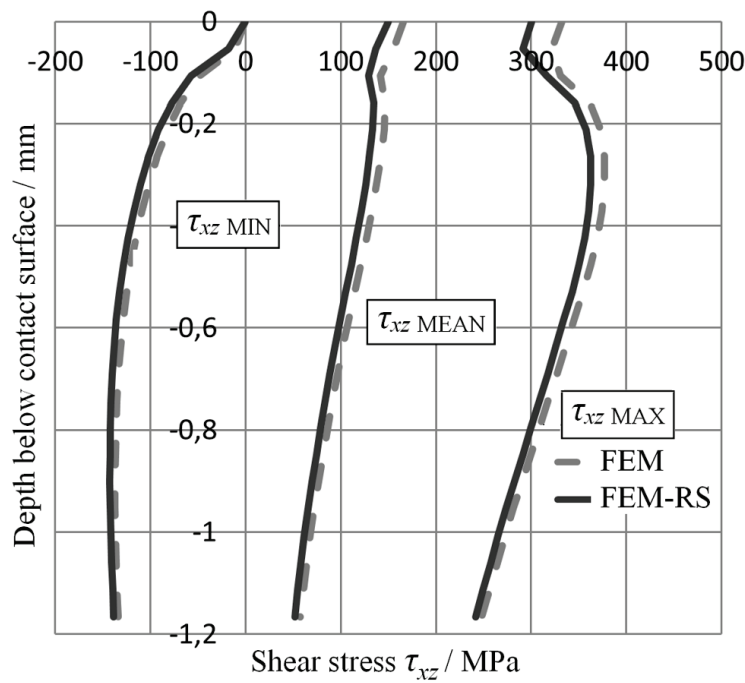

Figure 6 Trend of $\tau_{x z}$ with and without influence of residual stresses, including maximum, minimum, and mean stress values after 700 simulated cycles.

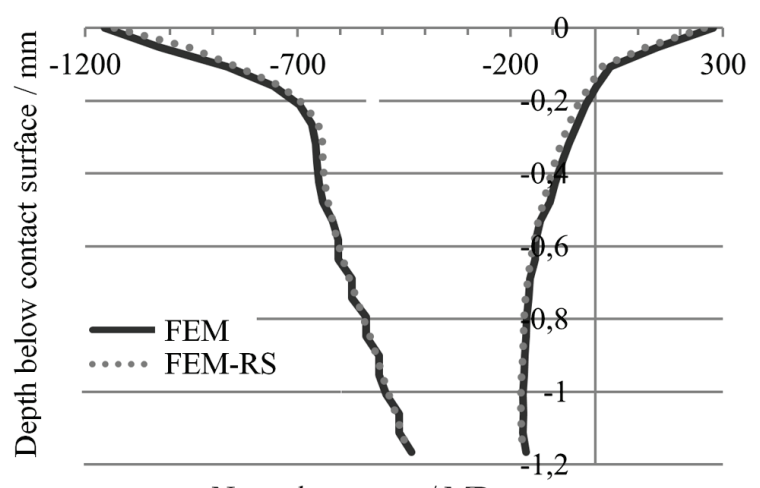

Normal stress $\sigma_{x} / \mathrm{MPa}$

Figure 7 Trend of $\sigma_{x}$ with and without influence of residual stresses, including maximum and minimum stress values after 700 simulated cycles.

\subsection{Ratcheting prediction for the Mazzu algorithm}

The Mazzu approach [14] is based on the non-linear kinematic hardening rule introduced by Lemaitre and Chaboche [27]. This approach is subsequently used for ratcheting prediction for rolling and rolling/sliding twodimensional contact. The model is based on the assumption of component $\tau_{x z}$, which is the only stress component responsible for ratcheting and plastic flow, respectively, in contact. According to [14], this hypothesis is reasonable in the case of subsurface flow where, according to the Melan theorem, the kinematic hardening process is mainly affected by shear stress $\tau_{x z}$, which varies within a larger range than other deviatoric stress components, irrespective of the friction coefficient.

In the Mazzu model [14], the elastic domain can be expressed as follows:

$$
F=\left|\sqrt{3} \cdot \tau_{x z}-X_{x z}\right|-\left(R+\sigma_{\mathrm{L}}\right) \leq 0
$$

where $\sigma_{L}$ is the initial tensile yield stress, $X_{x z}$ is the backstress expressing kinematic hardening, and $R$ is a variable expressing isotropic hardening. The occurrence of plastic strain will cause variations in the isotropic and kinematic hardening terms. The back-stress variation is expressed by the following equation:

$d X_{x z}=C \cdot \frac{d \gamma_{x z}}{\sqrt{3}}-\gamma \cdot X_{x z}\left|\frac{d \gamma_{x z}}{\sqrt{3}}\right|$

where $C$ and $\gamma$ are material parameters. The variation in the isotropic term is given by

$R=R_{\infty} \cdot\left[1-\mathrm{e}^{-b \cdot \frac{\gamma x z}{\sqrt{3}}}\right]$

where $R_{\infty}$ and $b$ are material parameters. Generally, $R_{\infty}$ will be greater than zero if the material hardens and less than zero if the material softens. The isotropic term tends asymptotically to $R_{\infty}$, so if the plastic flow is sufficiently large, the isotropic term can be considered constant. Eq. (2) can be integrated analytically to give

$$
X_{x z}=v \cdot \frac{C}{\gamma}+\left(X_{x z}^{0}-v \cdot \frac{C}{\gamma}\right) \exp \left[-\frac{v \cdot \gamma}{\sqrt{3}} \cdot\left(\gamma_{x z}-\gamma_{x z}^{0}\right)\right] \text {, }
$$

from where we can finally derive the relation for the plastic shear strain increment:

$$
\Delta \gamma_{x z}=-\frac{\sqrt{3}}{v \cdot \gamma} \cdot \ln \left(\frac{X_{x z}-v \cdot \frac{C}{\gamma}}{X_{x z}^{0}-v \cdot \frac{C}{\gamma}}\right),
$$

where $v=1$ for loading and $v=-1$ for unloading; $\gamma_{x z}^{0}$ and $X_{x z}^{0}$ are the initial conditions given by the values at the end of the previous cycle (step). From Eq. (1) we can obtain the relation for shear stress as a function of the back-stress and the isotropic variable, respectively.

$\tau_{x z}=\frac{1}{\sqrt{3}} \cdot\left[X_{x z}+v \cdot\left(R+\sigma_{\mathrm{L}}\right)\right]$ 
On the basis of the comparative simulations, we decided to add another term in the isotropic variation expression:

$$
R=R_{1 \infty} \cdot\left[1-\mathrm{e}^{-b_{1} \cdot \frac{\gamma_{x z}}{\sqrt{3}}}\right]+R_{2 \infty} \cdot\left[1-\mathrm{e}^{-b_{2} \cdot \frac{\gamma_{x z}}{\sqrt{3}}}\right] .
$$

The addition of one more Voce rule allows the isotropic variable to be controlled more flexibly.

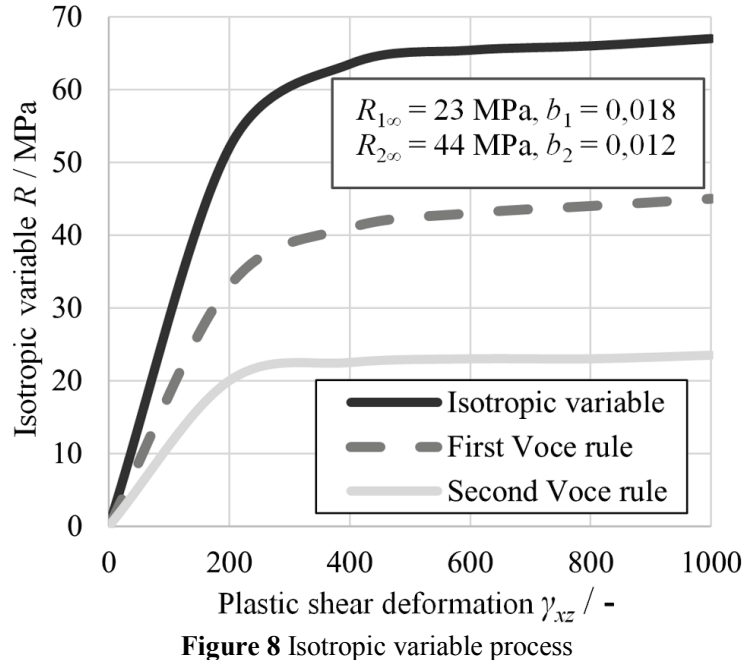

Fig. 8 (above) displays the isotropic variable that was used in later computations. According to the Mazzu model, the plastic shear strain accumulation is mainly influenced by shear stress $\tau_{x z}$. Figs. 9 and 10 display the stress variation for particular conditions at depths of 0,02 and $0,16 \mathrm{~mm}$ below the contact surface. It can be seen that the hypothesis is not valid at a depth of $0,02 \mathrm{~mm}$, where the shear stress is not significantly varying. Mazzu therefore published a modification to the algorithm [15] in the sense of applying two correcting functions:

$$
\begin{aligned}
& f_{1}(G)=0,25 \cdot\{\tanh [100 \cdot(G-0,634)]+3\}, \\
& f_{2}(G)=3,2 \cdot\left(1-f_{1}(G)\right) \cdot(1-G)^{0,6}+2 \cdot f_{1}(G)-1,
\end{aligned}
$$

which suitably regulate the extent of the surface plasticity

$F=\left|\sqrt{3} \cdot \tau_{x z}-X_{x z}\right|-f_{1}(G) \cdot\left(R+\sigma_{\mathrm{L}}\right) \leq 0$,

and the $C / \gamma$ ratio in Eq. (5)

$\Delta \gamma_{x z}=-\frac{\sqrt{3}}{v \cdot \gamma} \cdot \ln \left(\frac{X_{x z}-v \cdot \frac{C}{f_{2}(G) \cdot \gamma}}{X_{x z}^{0}-v \cdot \frac{C}{f_{2}(G) \cdot \gamma}}\right)$,

where $G$ is the ratio between the average value and the half-amplitude value of the $\sigma_{x z}$ variation:

$$
G=\left|\frac{\sigma_{x_{-} \mathrm{av}}}{\sigma_{x_{-} \text {alt }}}\right| .
$$

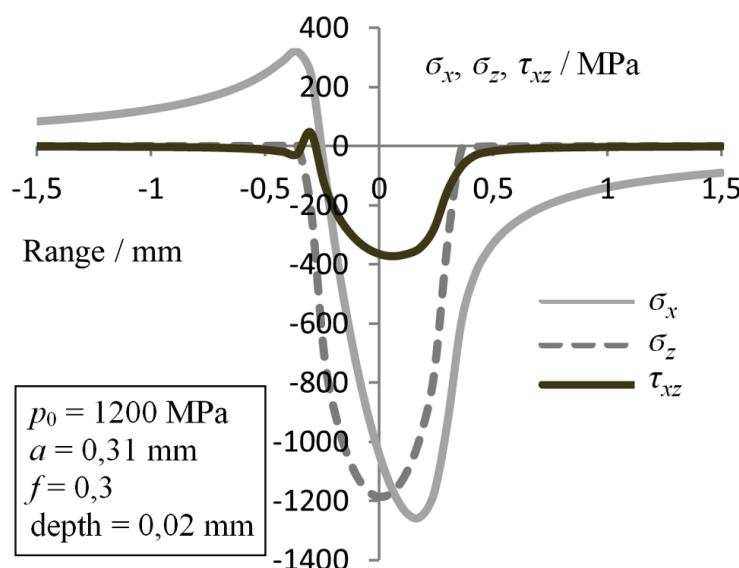

Figure 9 Stress variation for particular conditions at a depth of $0,02 \mathrm{~mm}$ below the contact surface

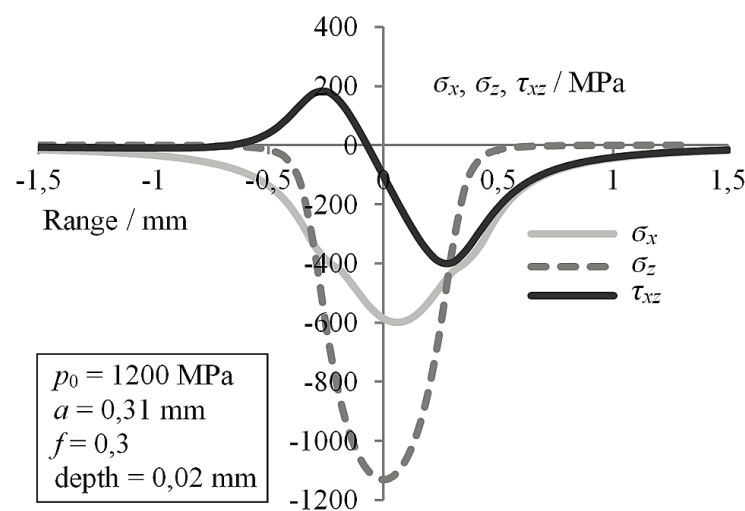

Figure 10 Stress variation for particular conditions at a depth of 0,16 $\mathrm{mm}$ below the contact surface

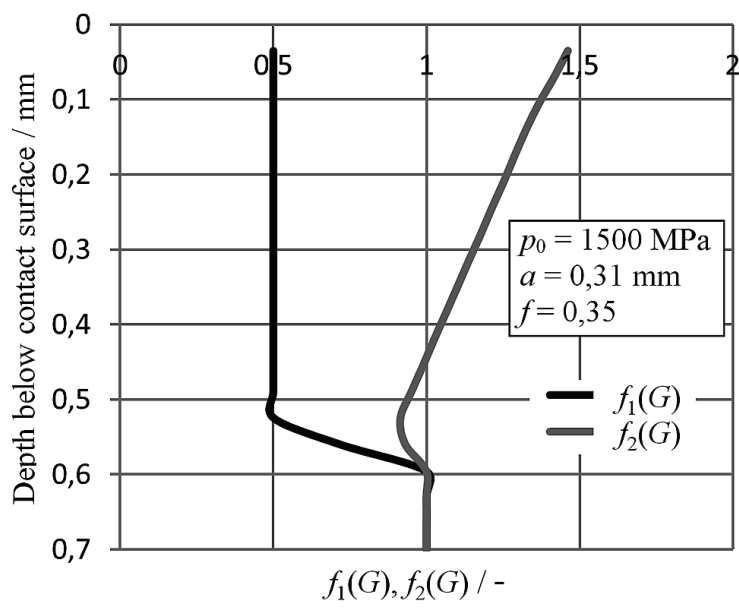

Figure 11 Dependence of correcting functions on depth below the contact surface for particular conditions

Fig. 12 shows how the correcting functions (Fig. 11) influence the plastic shear strain accumulation process under the given conditions after 500 simulated cycles for particular conditions.

According to Mazzu [14], wear is considered as an independent simultaneous phenomenon that progressively removes layers of material from the surface and influences the plastic strain accumulation (Fig. 13). In other words, if the critical strain $\gamma_{\text {crit }}$ is reached at a particular depth, then all material layers above will be considered as removed material. This shear band cracking wear mechanism was also published in [1]. 


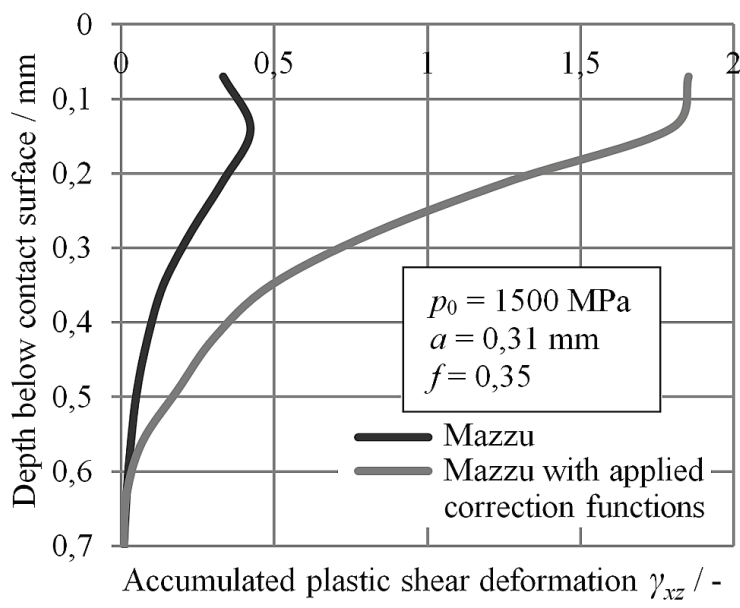

Figure 12 Influence of correcting functions on the plastic shear stress accumulation process after 500 simulated cycles

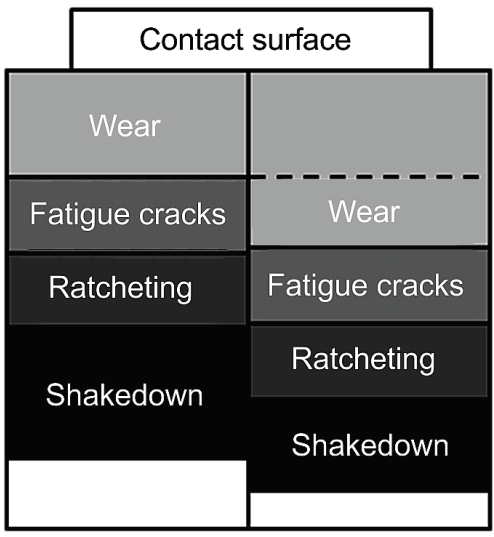

Figure 13 Wear process on the basis of the shear band cracking mechanism

\subsubsection{Calibration of Chaboche plasticity model}

In contrast to [1], the material parameters for further calculation of the deformation profiles using Mazzu's approach were obtained with the aim of using a numerical approach developed by J. Rojíček and R. Halama. Due to the nature of the task, we were not able to use an optimization algorithm that incorporated a particular gradient method. The reason was that the parameters varied extremely in dependence on one another, so that we would not be able to find the minimum of the complex function with optional mathematical and physical interpretation. In the first step, we have to specify the initial parameters of the Chaboche plasticity model (according to experiments with the same material under same conditions). The random number generator [28] then creates a unique set of parameters, which is used for four computations of the wear layer under a prescribed reference number of cycles. It is worth mentioning that the generator works on the basis of generating numbers with a uniform distribution pattern. In the beginning, we are able to specify the intervals from which the random values of the particular parameters have to be chosen. The iterative character of the algorithm consists in imposing a given set of parameters if a smaller error value is achieved in the wear calculation than in the previous step. A total of four computations are made per cycle, where the error value is computed in the following way:

$$
\operatorname{error}^{i}=\frac{1}{3} \cdot \sum_{k=1}^{4}\left(2 \cdot \frac{\left|N_{\mathrm{ref} k}-N^{k}\right|}{N_{\mathrm{ref} k}}+\frac{\left|h_{W \mathrm{ref} k}-h_{W}{ }^{k}\right|}{h_{W \mathrm{ref} k}}\right),
$$

where $N_{\text {ref } k}$ is the reference number of cycles, $N^{k}$ is the number of cycles, obtained with the Mazzu algorithm, needed to reach $h_{W}{ }^{k}$, and $h_{W \text { ref } k}$ is the reference value of the worn layer, coupled with the value of cycles $N_{\text {ref } k}$. The reference values $\left(N_{\text {ref } k}, h_{W \text { ref } k}\right)$ are gained from the proven linear relationship between the wear rate and the number of cycles for the particular experiment.

Eq. (13) shows that greater emphasis is put on the number of cycles $N^{k}$ calculated by Mazzu's algorithm, and $N^{k}$ is expressed with a weighting factor of 2. The following lines present the details of the realized experiment from which the required experimental data were obtained:

Material: R7T

Maximum Hertz contact pressure $p_{0}=1200 \mathrm{MPa}$

Hertz contact half-width $a=0,723 \mathrm{~mm}$

Average value of friction coefficient $f=0,33$

Slip $\xi=0,75 \%$

Test duration: 100000 cycles

Critical value of accumulated plastic shear strain: 9,1

Table 1 Initial and optimized material parameters for the case of an elasto-plastic stress field

\begin{tabular}{|c|c|c|c|}
\hline \multicolumn{2}{|c|}{ Initial parameters } & \multicolumn{2}{c|}{ Optimized parameters } \\
\hline $\begin{array}{c}\text { Material } \\
\text { parameter }\end{array}$ & Value & $\begin{array}{c}\text { Material } \\
\text { parameter }\end{array}$ & Value \\
\hline$C / \mathrm{MPa}$ & 40000 & $C / \mathrm{MPa}$ & 47234 \\
\hline$\gamma /-$ & 2 & $\gamma /-$ & 2,684 \\
\hline$\sigma_{\mathrm{L}} / \mathrm{MPa}$ & 305 & $\sigma_{\mathrm{L}} / \mathrm{MPa}$ & 334 \\
\hline$R_{1 \infty} / \mathrm{MPa}$ & 30 & $R_{1 \infty} / \mathrm{MPa}$ & 23 \\
\hline$R_{2 \infty} / \mathrm{MPa}$ & 50 & $R_{2 \infty} / \mathrm{MPa}$ & 44 \\
\hline$b_{1} /-$ & 0,05 & $b_{1} /-$ & 0,018 \\
\hline$b_{2} /-$ & 0,005 & $b_{2} /-$ & 0,012 \\
\hline
\end{tabular}

Our main goal is to determine the thickness of the worn layer after 500000 cycles with the use of Mazzu's approach. For the purpose of accurately identifying the material parameters, we need to calculate the wear data in the interval between 100000 and 500000 cycles, based on the linear relationship between wear and the number of cycles [14]. The initial and optimized material parameters are listed in Tab. 1. They were calculated using the algorithm presented here for the case of the elasto-plastic stress field obtained using FEM and taking into consideration the residual stresses as initial stresses.

Table 2 Initial and optimized material parameters for the case of a purely elastic stress field

\begin{tabular}{|c|c|c|c|}
\hline \multicolumn{2}{|c|}{ Initial parameters } & \multicolumn{2}{c|}{ Optimized parameters } \\
\hline $\begin{array}{c}\text { Material } \\
\text { parameter }\end{array}$ & Value & Material parameter & Value \\
\hline$C / \mathrm{MPa}$ & 40000 & $C / \mathrm{MPa}$ & 68339 \\
\hline$\gamma /-$ & 2 & $\gamma /-$ & 2,972 \\
\hline$\sigma_{\mathrm{L}} / \mathrm{MPa}$ & 370 & $\sigma_{\mathrm{L}} / \mathrm{MPa}$ & 415 \\
\hline$R_{1 \infty} / \mathrm{MPa}$ & 130 & $R_{1 \infty} / \mathrm{MPa}$ & 103 \\
\hline$R_{2 \infty} / \mathrm{MPa}$ & 35 & $R_{2 \infty} / \mathrm{MPa}$ & 20 \\
\hline$b_{1} /-$ & 0,03 & $b_{1} /-$ & 0,014 \\
\hline$b_{2} /-$ & 0,0001 & $b_{2} /-$ & 0,0005 \\
\hline
\end{tabular}


Tab. 2 summarizes the material parameters, which were optimized according to the purely elastic stress field, obtained from the Boussinesq approximation.

\section{Results}

A total of three computations were made with the aim of obtaining the plastic shear profile under the worn layer after 500000 cycles, using the Mazzu algorithm. Fig. 14 shows the plastic shear strain profile results and also the depth of the worn layer depending on the stress field that is used in the computation.

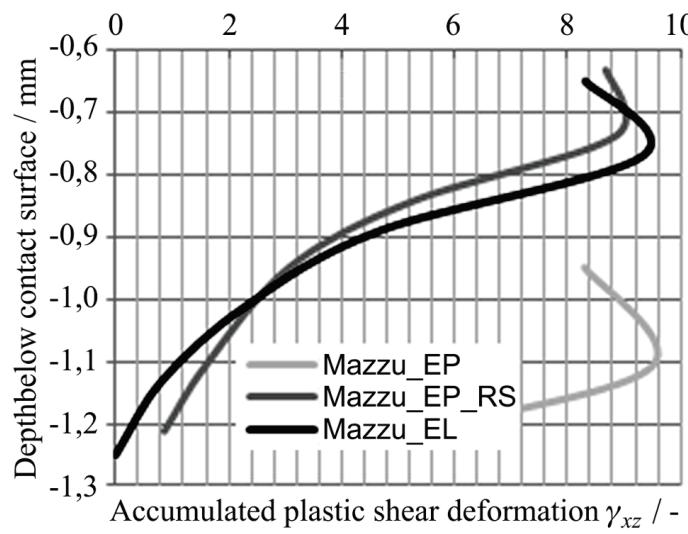

Figure 14 Plastic shear stress deformation profiles after 500000 simulated cycles obtained by various approaches

In two cases, we used the stress field from an elastoplastic FEM simulation with and without the influence of residual stresses. The third computation was carried out on the basis of the purely elastic stress field, using the Boussinesq method. It can be seen that the shear strain profiles calculated under an elasto-plastic stress field with the influence of the residual stresses and the elastic stress field tend to be somewhat similar in shape, and the depth of the worn layer is in both cases equal to approximately $0,53 \mathrm{~mm}$, while the extrapolated value of the worn layer from the experimental data after 500000 cycles is equal to $0,56 \mathrm{~mm}$. However, the worn depth in the case of an elasto-plastic stress field without the influence of residual stresses is equal to $0,84 \mathrm{~mm}$. The results presented here show that the compressive technological residual stresses undoubtedly reduce the thickness of the worn layer and, at the same time, increase the durability.

\section{Conclusion}

The Mazzu algorithm presented here [1] enables the user not only to determine the wear rate for particular loading conditions but also, especially, to analyse and assess the evolution of the accumulation of plastic shear strain beneath the contact surface. Three semi-analytical calculations were performed: for an elasto-plastic stress field with and without the influence of residual stresses, and for a purely elastic stress field. In the first two cases, the stress fields were obtained in order to carry out an FEM analysis and the purely elastic stress field was obtained with the help of the Boussinesq hypothesis.

A new procedure has been proposed for calibrating the Mazzu model directly from wear experimental data. Despite the simple principle implemented in the form of a random number generator, the inverse algorithm proves to be an effective tool for identifying the material parameters.

It has been shown that the Mazzu algorithm can also use the results of elasto-plastic stress FEM as an input. This makes it possible to consider technological residual stresses in predicting ratcheting and wear. It is clear from the results of the FE analyses performed using the modified AbdelKarim-Ohno cyclic plasticity model that the compressive residual stresses observed by the X-ray and hole-drilling methods decrease the ratcheting rate on the surface by more than $30 \%$ after 700 cycles (Fig. 4). The wear calculations using the Mazzu algorithm give a worn layer about $60 \%$ smaller after 500000 simulated cycles, taking into account the initial compressive residual stresses. The results of this study confirm that technological compressive residual stresses lead to lower ratcheting and subsequently also to lower wear rates. The proposed method can be used for evaluating various surface treatment conditions that are widely used in practical applications from the point of view of wear resistance.

\section{Acknowledgments}

This work has been elaborated in the framework of the IT4Innovations Centre of Excellence project, reg. no. CZ.1.05/1.1.00/02.0070, supported by the Operational Programme Research and Development for Innovations and funded from the Structural Funds of the European Union and from the state budget of the Czech Republic; in the framework of the project Opportunity for Young Researchers, reg. no. CZ.1.07/2.3.00/30.0016, supported by Operational Programme Education for Competitiveness and co-financed by the European Social Fund and the state budget of the Czech Republic; and also in the framework of project no. 15-18274S supported by the Grant Agency of the Czech Republic (GACR).

\section{References}

[1] Guerrieri, M.; Parla, G.; Ticali, D. A theoretical and experimental approach to reconstructing the transverse profile of worn-out rails. // Ingegneria Ferroviaria. 67, 1(2012), pp. 23-37.

[2] Tumanishvili, G.; Nadiradze, T.; Tumanishvili, I. Improving of operating ability of wheels and rail tracks. // Transport Problems. 9, 3(2014), pp. 99-105.

[3] Donzella, G.; Faccoli, M.; Mazzu, A.; Petrogalli, C.; Roberti, R. Progressive damage assessment in the nearsurface layer of railway wheel-rail couple under cyclic contact. // Wear. 271, (2011), pp. 408-416. DOI: 10.1016/j.wear.2010.10.042

[4] Tyfour, W. R.; Beynon, J. H.; Kapoor, A. The steady state wear behaviour of pearlitic rail steel under dry rollingsliding contact conditions. // Wear. 180, (1995), pp. 79-89. DOI: 10.1016/0043-1648(94)06533-0

[5] Fletcher, D. I.; Beynon, J. H. Equilibrium of crack growth and wear rates during unlubricated rolling-sliding contact of pearlitic rail steel. // Proceedings of the Institution of Mechanical Engineers Part F. 214, (2000), pp. 93-105. DOI: 10.1243/0954409001531360

[6] Tyfour, W. R.; Beynon, J. H.; Kapoor, A. Deterioration of rolling contact fatigue life of pearlitic rail due to dry-wet 
rolling-sliding line contact. // Wear. 197, (1996), pp. 255265. DOI: 10.1016/0043-1648(96)06978-5

[7] Kapoor, A.; Franklin, F. J. Tribological layers and the wear of ductile materials. // Wear. 245, (2000), pp. 204-215. DOI: 10.1016/S0043-1648(00)00480-4

[8] Merwin, J. E.; Johnson, K. L. An analysis of plastic deformation in rolling contact. // Proceedings of the Institution of Mechanical Engineers 177, 25(1963), pp. 676-685. DOI: 10.1243/PIME_PROC_1963_177_052_02

[9] Bower, A.F.; Johnson K.L. The influence of strain hardening on cumulative plastic deformation in rolling and sliding line contact.// Journal of the Mechanics and Physics of Solids, 37 (1989), pp. 471-493. DOI: 10.1016/00225096(89)90025-2

[10] Dang Van, K.; Maitournam, M. H. Steady-state flow in classical elastoplasticity: Applications to repeated rolling and sliding contact. // Journal of the Mechanics and Physics of Solids. 41, (1993), pp. 1691-1710. DOI: 10.1016/00225096(93)90027-D

[11] Dang Van, K.; Maitournam, M. H. Elastoplastic analysis of repeated moving contact: Application to railways damage phenomena. // Wear. 196, (1996), pp. 77-81. DOl: 10.1016/0043-1648(95)06864-3

[12] Dang Van, K.; Maitournam, M. H. Rolling contact in railways: modeling, simulation and prediction. // Fatigue \& Fracture of Engineering Materials \& Structures. 26(2003), pp. 939-948. DOI: 10.1046/j.1460-2695.2003.00698.x

[13] Jiang, Y.; Sehitoglu, H. An analytical approach to elasticplastic stress analysis of rolling contact. // Journal of Tribology. 116, (1994), pp. 577-587. DOI: 10.1115/1.2928885

[14] Mazzu, A. A simplified non-linear kinematic hardening model for ratcheting and wear assessment in rolling contact. // Journal of Strain Analysis. 43, 5(2008), pp. 349-360. DOI: 10.1243/03093247JSA405

[15] Mazzu, A. Surface plastic strain in contact problems: prediction by a simplified non-linear kinematic hardening model. // Journal of Strain Analysis. 44, 3(2009), pp. 187199. DOI: $10.1243 / 03093247 J S A 480$

[16] Seo, J. W.; Goo, B. C.; Choi, J. B.; Kim, Y. J. Effects of metal removal and residual stress on the contact fatigue life for railway wheels. // International Journal of Fatigue. 30(2008), pp. 2021-2029. DOI: 10.1016/j.jfatigue.2007.12.003

[17] Choi Y. A study on the effects of machining-induced residual stress on rolling contact fatigue. // International Journal of Fatigue. 31(2009), pp.1517-1523. DOl: 10.1016/j.jifatigue.2009.05.001

[18] Halama, R.; Fajkoš, R.; Matušek, P.; Bábková, P.; Fojtík, F.; Václavek, L. Contact defects initiation in railroad wheels - Experience, experiments and modeling. //Wear. 271, (2011), pp. 174-185. DOI: 10.1016/j.wear.2010.10.053

[19] Ganev, N.; Kraus, I. On the application of X-ray tensometry to states of stress due to tangential machining of metal surfaces. // Physica Status Solidi A. 106, (1988), pp. 467472. DOI: $10.1002 /$ pssa.2211060217

[20] Maximov, J. T.; Duncheva, G. V.; Ganev, N.; Amudjev, I. M. Modeling of residual stress distribution around fastener holes in thin plates after symmetric cold expansion. // Journal of the Brazilian Society of Mechanical Sciences and Engineering. 36, (2014), pp. 355-369. DOl: 10.1007/s40430-013-0090-2

[21] Kolařík, K.; Ganev, N.; Pala, Z. About the capability of Xray diffraction technique for diagnostic of technological residual stresses. // Proceedings of the $48^{\text {th }}$ International Scientific Conference "Experimental Stress Analysis 2010". Palacky University, Olomouc, Czech Republic, (2010), pp. 161-168.

[22] Kraus, I.; Ganev, N. X-ray analysis of the inhomogeneous stress state. // Defect and Microstructure Analysis by Diffraction. Oxford: Oxford University Press, 1999, pp. 367-401.
[23] ASTM E 837 - 08, Standard Test Method for Determining Residual Stresses by the Hole-Drilling Strain - Gage Method, 2008.

[24] Schayer, G. S. Measurement of non-uniform residual stresses using the hole drilling method. // Journal of Engineering Materials and Technology. 110, 4(1988), Part I: pp. 338-343, Part II: pp. 344-349.

[25] D 24.32.0, Strain Gage Rosette RY 61 with Leading and Milling Guide, Tech Note of HBM, 1983.

[26] Tech Note TN 503-5, Measurement of Residual Stresses by Hole-Drilling Strain Gage Method, Vishay, 1993

[27] Lemaitre, J.; Chaboche, J. L. Mechanics of Solid Materials. Cambridge University Press, Cambridge, 1994.

[28] Famfulík, J.; Míková, J.; Lánská, M.; Richtář, M. A stochastic model of the logistics actions required to ensure the availability of spare parts during maintenance of railway vehicles. // Proceedings of the Institution of Mechanical Engineers, Part F: Journal of Rail and Rapid Transit. 228, 1(2014), pp. 85-92. DOI: $10.1177 / 0954409712465695$

\section{Authors' addresses}

Radim Halama, Doc., PhD.

Michal Šfer, Ing., PhD.

Jaroslav Rojíček, Ing., PhD

František Fojtik, Ing., PhD.

VSB-TU Ostrava,

17. listopadu 15/2127, 70833 Ostrava-Poruba, Czech Republic radim.halama@vsb.cz

michal.sofer@vsb.cz

jaroslav.rojicek@vsb.cz

frantisek.fojtik@vsb.cz

Kamil Kolařik, Ing., PhD.

CTUin Prague

Trojanova 13, 12000 Prague 2, Czech Republic

kamil.kolarik@email.cz 